\title{
Development of Religious and Moral Values on 4-5 Years Old Children in Imitating Prayer Movement (Shalat) Using Simulation and Rewarding Methods
}

\author{
Wahyu*, Maimunah \\ Department of Early Childhood Education, Universitas Lambung Mangkurat, Banjarmasin, Indonesia.
}

\begin{tabular}{l|l}
\hline \multicolumn{1}{c|}{ A R T I C L E I N F O } & \multicolumn{1}{c}{ A B S T R A C T } \\
\hline $\begin{array}{l}\text { Received: 09-03-20I7 } \\
\text { Revised: 08-05-20I7 }\end{array}$ & $\begin{array}{l}\text { The objectives of this study are to identify the description of teacher activity in } \\
\text { performing steps of simulation method added by giving reward, children activity in } \\
\text { learning as well as the result of children's religious and moral values development in } \\
\text { imitating prayer movement. This research is qualitative that using classroom action } \\
\text { research type that taking place on Akhlaqul Karimah Kindergarten East Banjarmasin } \\
\text { Keywords: }\end{array}$ Activity, religious, moral \\
values, prayer movement, & $\begin{array}{l}\text { values in imitating prayer movement using simulation method and giving reward can } \\
\text { improve teacher's and children activity from cycle I improved to cycle II and the } \\
\text { development results of children's religious and moral values from Cycle I and Cycle } \\
\text { II also improved. }\end{array}$ \\
\cline { 2 - 3 } & $\begin{array}{l}\text { C 2018 The Authors. Journal of K6, Education, and Management (j-K6EM). ISSN: 2580-2135. } \\
\text { Published by Graduated Program of Educational Management, Universitas Lambung } \\
\text { Mangkurat, Banjarmasin, Indonesia. This is an open access article under the open journal } \\
\text { systems 3. }\end{array}$ \\
\hline
\end{tabular}

*Author correspondence: Wahyu; E-mail: wahyu.psdulm@gmail.com 


\section{Introduction}

Early childhood ranges from birth to six years old are both critical and strategic age in educational process and may affect the process and outcomes of someone further education. It means that this is conducive period for developing the skill, talent, physical, cognitive, language, socialemotional and spiritual (Yamin \& Sanan, 2010).

According to Fadlillah and Lilif (2013) religious attitude can be instilled in early childhood by providing various religious activities for children. For instance, teaching the children to pray together, prayer before eating, and instilling mutual respect towards peers who have different religions.

Shalat (pray) is the second pillar of Islam. Shalat is accepted if it meets all the requirements and the pillars. Performing Shalat is obligated as performing other obligations (Ahmadi and Salimi, 2008). According to Hanafi, Shalat movements consist of: standing towards the Qiblah, takbiratul ihram, recite iftitah, recite Alfatihah, ruku (bowing), ittidal (rise from the ruku) first prostration, sit between two prostrations, sit for the last tasyahud, greetings to the right and left.

In accordance with Regulation of the Minister of National Education Number 58 of 2009 on early childhood education standards, stating a standard of development achievement level. From the aspect of behavioral development including religious and moral values, the standard of development achievement level for age $4<5$ years old is that children are expected to be able to mimic prayer movements at that age.

Based on the fact at Akhlaqul Karimah Kindergarten East Banjarmasin District, on group A children aged $4<5$ years old, there are children who are not yet able to imitate the prayer movement, especially on the movement of prayer. There are children who are not yet able to imitate the prayer movement prayer in sequence correctly. From the children development report (report card) on the last semester I academic year of 2013/20I4 and observation result data as well as interview with homeroom teacher on December 19, 2013, there are children who have not developed yet in terms of the development achievement of children age $4-<5$. From 18 children, it was only about $27.8 \%$ or 5 children who could imitate the prayer movements (Shalat) properly and sequentially, and $72.2 \%$ or 13 children who could not mimic the prayer movements (Shalat) properly and sequentially. Shalat is the second pillar of Islam. Shalat is accepted if it meets all the requirements and the pillars. Performing Shalat is obligated as performing other obligations (Ahmadi \& Salimi, 2008).

According to Suriansyah and Aslamiah (20II) teaching and learning activity is a unity of two in line activities. Learning is the primary in teaching and learning activity, while teaching is the secondary which is intended to conduct an optimal teaching and learning activities. The situation enabling the learning activity is by the interaction of the children with teacher and or learning in certain places that have been set in order to achieve the learning objectives. In addition, the situation could optimize the learning activity if it is supported by proper methods or media.

Simulation method is a practical method which helps to develop the learners' skills (mental or physical skill). This method brings the real situation into the activities or classroom due to the difficulties to practice in the real situation. Simulation method is like role playing. However, in this method, the learners act as themselves more in performing an activity or task they perform.

Reward means appreciation. While in terminology, rewards may mean gifts or positive reinforcements. According to Maslow (Wantah, 2005) reward is one of basic needs that encourage someone to actualize himself. Reward is one of learning tools in education world. As a tool, Reward has important meaning in fostering the learners' character.

\section{Methodology}

A good methodology should bring the researcher to achieve of the objective (Dalle, 2010; Dalle et al., 2017). This research is a qualitative study. It focused on human and the interactions in social context. This research is Classroom Action 
Research conducted in 2 cycles with two meetings in every cycle. Therefore, research subject is used instead of research object as in quantitative research. The used of research subject also shows respect the children as the object under studied. This research used qualitative approach focusing on human and the interactions in social context. Therefore, research subject is used instead of research object as in quantitative research. The used of research subject also shows respect the children as the object under studied.

The factors studied was teacher activity in learning using simulation and reward method, children activity in learning using simulation and reward method as well as the results of religious and moral values development in imitating prayer movements by using simulation and reward methods.

\section{Results and Discussion}

The results of the research indicated improvement of aspects of religious and moral values in imitating prayer movement using simulation and giving reward methods can improve teachers' activity from cycle I to cycle II in with excellent result reached $97.5 \%$, as well as children's activity increased in cycle II meeting II reached $93.40 \%$ with Qualification of Very Active. The results of religious and moral values development of children from Cycle I and Cycle II were also improved. It achieved classical mastery of 100\% or in Developing as Expected criteria.

Teachers' activity in developing religious and moral values aspect of children in imitating prayer movements improved from Cycle I meeting I which achieved $60 \%$ of implementation included in Fair criteria, and improved at the end of Cycle II achieved $97.5 \%$ of implementation with criteria of teacher activity quality achieved Very Good category. In the implementation of learning using simulation and providing reward methods, teacher is not the only source in conducting teaching-learning process. Teacher is not only as a presenter of the material. Learning is not only centered on the teacher but in the implementation of this learning, the teacher also acts as a facilitator, motivator, mentor, and evaluator in the learning process activities.
At the beginning, on cycle I meeting i, children activity achieved only $57.99 \%$ with qualification of quite active. at the end of the meeting of cycle ii meeting ii, the results of children activity improved to $93.40 \%$ with qualification of Active. Then, it can be concluded that in this research, children activities have improved in each meeting.

The results of children development improved at the end of the research, in cycle II meeting II was 9 children or $50 \%$ of children earned developing very good and 9 children or $50 \%$ of children earned developing as expected criteria. For these reasons, it can be concluded that the development of religious and moral values aspect classically reached $\geq 80 \%$ achieving successful indicator even $100 \%$ of children earned developing as expected, so it achieved the successful indicator of religious and moral values aspect results.

\section{Conclussion and Recomendations}

It can be concluded that in this research, teacher activity, children activity had improved reaching the successful indicator and the results of religious and moral values development of children achieved Developing as Expected criteria.

Based on the results, our recommendations are (I) The teachers are suggested to make simulation and providing reward methods as alternative in selecting learning method. It can improve the professionalism in managing the quality, active, creative, effective, interactive, and fun learning in order to developing religious and moral values aspect in imitating prayer movements; (2) For Kindergarten Principal, should promote fostering the teachers in selecting learning methods which is adjusted to the concept of learning through playing as inputs for learning in the classroom so that the learning quality in Early Childhood Education in general and Kindergartens in particular can increases; (3) For the future researcher who wants to use simulation and providing reward method, needs to pay more attention to the time allocation well, so that the implementation of the simulation can run optimally. Moreover, the future researcher should consider and estimate the reward will be given to the child in every meeting. In addition, the researcher could add pictures as a media and make this research as the reference to add insight about simulation and providing reward methods 
in order to be able to implement it in Early Childhood Education learning.

\section{Acknowledgment}

No acknowledgment

\section{References}

Dalle, J. (2010). Metodologi umum penyelidikan reka bentuk bertokok penilaian dalaman dan luaran: Kajian kes sistem pendaftaran siswa Indonesia. Thesis PhD Universiti Utara Malaysia.

Dalle, J., Hadi, S., Baharuddin., \& Hayati, N. (2017). The Development of Interactive Multimedia Learning Pyramid and Prism for Junior High School Using Macromedia Authorware. The Turkish Online Journal of Educational Technology, November. 7I4-72I.

Djamarah, S.B. (2005). Guru dan anak didik dalam interaksi edukatif. Jakarta: Rineka Cipta

Fadlillah, \& Lilif, K. (2013). Pendidikan karakter anak usia dini (konsep dan aplikasinya). Yogyakarta: Ar-Ruzz Media.

Suriansyah, A., \& Aslamiah. (20II). Strategi pembelajaran anak usia dini. Banjarmasin: Comdes.

Wantah, M.J. (2005). Pengembangan disiplin dan pembentukan moral pada anak usia dini. Jakarta: Depdiknas.

Yamin, M., \& Sanan, S.J. (20I0). Panduan pendidikan anak usia dini. Jakarta: Gaung Persada Press. 